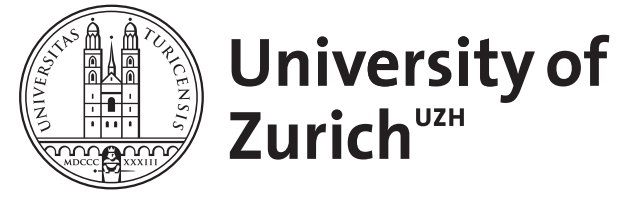
Archive

University of Zurich

University Library

Strickhofstrasse 39

CH-8057 Zurich

www.zora.uzh.ch

Year: 2010

Beneath the nimbus-the hair of the saints

Trüeb, R M ; Navarini, A A

DOI: https://doi.org/10.1001/archdermatol.2010.103

Posted at the Zurich Open Repository and Archive, University of Zurich

ZORA URL: https://doi.org/10.5167/uzh-43115

Journal Article

Originally published at:

Trüeb, R M; Navarini, A A (2010). Beneath the nimbus-the hair of the saints. Archives of Dermatology, 146(7):764.

DOI: https://doi.org/10.1001/archdermatol.2010.103 


\section{Beneath the Nimbus-The Hair of the Saints}

From the beginning of civilization, man has placed importance on the appearance and symbolism of hair. The psychosocial significance and religious connotation of hair are well known. Hair has 2 perceived symbolic meanings in a spiritual context: shaven hair is a symbol of celibacy and chastity, while uncut hair is seen as withdrawal from worldly concerns and vanities. Religious tradition is a plentiful source of accounts of hopes and fears related to the human condition. These hopes and fears are reflected in Christian hagiography and iconography. While the former deals with the accounts of the saints' lives, the latter relates to the saints' depiction in art. Appreciation of religious art is deepened by a knowledge of what is depicted and why. Roman Catholic churches are replete with images of saints. Since saints are seldom labeled with their names, clues to their identity are given by their attributes, ie, by their appearance or what object they are holding. These attributes may be the instruments of martyrdom, representations of events in their lives, or symbols of their teachings.

Peculiarities relating to the hair of saints (Table) are facial hirsutism (St Wilgefortis); generalized hypertrichosis (St Onuphrius); long, disheveled hair (St Mary of Egypt); long, beautiful hair (St Mary Magdalene); the miracle of hair growth (St Agnes of Rome); and overnight whitening of hair (St Thomas More). ${ }^{1}$ The role of hair during martyrdom is reflected by the accounts of St Perpetua, who asked for a pin to fasten her untidy hair in the hour of her martyrdom, lest she might seem to be mourning in her hour of triumph, and
St Margaret of Antioch, who was allegedly tortured while being suspended by her hair.

In studying the saints, the question arises, "Why saints?" Woodward ${ }^{2}$ states, "A saint is always someone through whom we catch a glimpse of what God is like-and of what we are called to be." Ultimately, saints help us to believe in miracles and miraculous healings. Roman Catholic tradition has made saints protectors of various aspects of life who are invoked for particular reasons. The affiliation of a protector saint to a specific condition relates to the lives of the saints and their depiction in art; eg, St Bartholomew is invoked for skin diseases because images of his martyrdom depict him with his skin draped over his arm. Therefore, the saints whose attributes relate to the hair would seem suitable candidates for trichological issues. ${ }^{3}$ Finally, understanding how hair is used as a symbol in the lives of the saints reveals its spiritual connection; after all, it is our skin appendage that is closest to heaven.

Ralph M. Trüeb, MD

Alexander A. Navarini, MD, PhD

Author Affiliations: Department of Dermatology, University Hospital of Zurich, Zurich, Switzerland.

Dr Trüeb is with the Department of Dermatology, Univer sity Hospital of Zurich, Zurich, Switzerland (Ralph.trueeb @usz.ch).

Table. Summary of Saints, Their Peculiarities, and the Symbolism of Their Hair

\begin{tabular}{|c|c|c|c|c|}
\hline & Mary Magdalene & Perpetua & Agnes of Rome & Margaret of Antioch \\
\hline Period & First century & Died 203 & 291-304 & Died 305 \\
\hline Sanctity & $\begin{array}{l}\text { Follower of Christ and the } \\
\text { Apostles }\end{array}$ & Martyr & Martyr & Martyr \\
\hline Account & New Testament (Luke) & Tertullian of Carthage & Jacobus de Voragine & Jacobus de Voragine \\
\hline Attributes & $\begin{array}{l}\text { Long, uncovered hair, } \\
\text { ointment vase }\end{array}$ & $\begin{array}{l}\text { In arena, usually together } \\
\text { with Felicity }\end{array}$ & Lamb & Dragon, cross \\
\hline Patronage & Hair stylists & Martyrs & $\begin{array}{l}\text { Girls, betrothed women, } \\
\text { virgins, rape victims, } \\
\text { gardeners }\end{array}$ & Childbirth \\
\hline Hair condition & Long, beautiful hair & Hair in martyrdom & Long hair & Hair as martyrdom \\
\hline \multirow[t]{2}{*}{ Symbolism } & Female attractiveness & Dignity & Chastity & Martyrdom \\
\hline & Onuphrius & Mary of Egypt & Wilgefortis & Thomas More \\
\hline Period & $320-400$ & $344-421$ & $\begin{array}{l}\text { Unknown, cult aroused in } \\
\text { 14th century }\end{array}$ & $1478-1535$ \\
\hline Sanctity & Hermit & Hermit & Martyr & Martyr \\
\hline Account & Paphnutius & Sophronius & $\begin{array}{l}\text { Popular religious } \\
\text { imagination }\end{array}$ & History of England \\
\hline Attributes & $\begin{array}{l}\text { Wild man completely } \\
\text { covered with hair, loin } \\
\text { girdle of leaves }\end{array}$ & $\begin{array}{l}\text { Long hair covering naked } \\
\text { body }\end{array}$ & Beard, crucifixion & Book, axe \\
\hline Patronage & Weavers & Penitents & Difficult marriages & Statesmen and politicians \\
\hline Hair condition & Generalized hypertrichosis & Long, disheveled hair & Facial hirsutism & Sudden whitening of hair \\
\hline Symbolism & $\begin{array}{l}\text { Withdrawal from worldly } \\
\text { concerns and vanities }\end{array}$ & $\begin{array}{l}\text { Withdrawal from worldly } \\
\text { concerns and vanities }\end{array}$ & Resistance & $\begin{array}{l}\text { Extreme psychological } \\
\text { stress }\end{array}$ \\
\hline
\end{tabular}

1. Trüeb RM, Navarini AA. Thomas More syndrome. Dermatology. 2010;220(1):55-56.

2. Woodward K. Making Saints: How the Catholic Church Determines Who Becomes a Saint, Who Doesn't, and Why. New York, NY: Touchstone/Simon and Schuster; 1996

3. Trüeb RMS. Agnes of Rome: patron saint for women with hair loss? Dermatology. 2009;219(2):97-98. 